\title{
CD36 and GPR120 Methylation Associates with Orosensory Detection Thresholds for Fat and Bitter in Algerian Young Obese Children
}

\author{
Moustafa Berrichi ${ }^{1,2}{ }^{\mathbb{D}}$, Aziz Hichami ${ }^{1}$, Lynda Addou-Klouche ${ }^{3}$, Amira Sayed Khan ${ }^{1}$ and \\ Naim Akhtar Khan 1,*(D) \\ 1 Physiologie de la Nutrition \& Toxicologie, U1231 INSERM/Université de Bourgogne-Franche \\ Comté (UBFC)/AgroSupDijon, 21000 Dijon, France; Moustafa.berrichi@univ-tlemcen.dz (M.B.); \\ aziz.hichami@u-bourgogne.fr (A.H.); amira.khan@u-bourgogne.fr (A.S.K.) \\ 2 Laboratoire de Biologie Moléculaire Appliquée et Immunologie, Université Abou Bakr Belkaid, \\ Tlemcen 13000, Algeria \\ 3 Faculté des Science de la Vie et de la Nature, Université Djillali Liabès, Sidi Bel Abbès 22000, Algeria; \\ klynad@yahoo.com \\ * Correspondence: Naim.Khan@u-bourgogne.fr; Tel.: +33-3-80-39-63-30-12
}

Received: 17 May 2020; Accepted: 22 June 2020; Published: 23 June 2020

\begin{abstract}
Background: The spontaneous preference for dietary fat is regulated by two lingual lipid sensors (CD36 and GPR120) in humans and rodents. Our objective was to investigate whether obesity in children is associated with methylation of lipid sensor genes, and whether this alteration was implicated in altered gustatory perception of fat and bitter and increased preference of palatable foods. Methods: School children were recruited and classified according to their body mass index (BMI) $z$-score into two groups: obese and lean children. The detection of orosensory perception for oleic acid and 6-n-propylthiouracil was assessed by using a 3-alternative forced-choice test. After blood DNA extraction, methylation patterns were investigated by methylation-specific PCR. The children were also subjected to a food habit questionnaire. Results: Obese children showed higher lipid and bitter detection thresholds than lean children. Besides, more obese children presented higher methylation level of the CPG sites than lean participants. Interestingly, CD36 and GPR120 gene methylation was associated with high lipid detection thresholds in obese participants. The obese participants preferred highly palatable fat-rich food items, associated with CD36 and GPR120 gene methylation. Conclusion: Epigenetic changes in CD36 and GPR120 genes might contribute to low orosensory perception of fat and bitter taste, and might be, consequently, critically involved in obesity in children
\end{abstract}

Keywords: CD36; GPR120; fat taste; obesity; bitter taste

\section{Introduction}

The incidence of obesity is on the rise throughout the world. Obesity is often associated with a plethora of disorders including type 2 diabetes, dyslipidemia, cancer, and hypertension [1]. Although the etiology of obesity is still unclear, the influence of culture, lifestyle, behavior, and genetic predisposition are suggested to have major contributions in disease development [2]. Obesity generally results from increased intake of high-calorie food and decreased expenditure due to low physical activity [3,4]. During recent years, childhood obesity has become one of the leading challenges of this century. Overweight and obese children are more prone to be obese in adulthood [5]. Childhood obesity is associated with many physiological and psychological disorders including elevated blood pressure, glucose intolerance, and low self-esteem, thus contributing to extra costs for 
health-care [6,7]. Early detection and prevention of childhood obesity can prevent and minimize the burden of such comorbidities [6].

Basically, there are five taste qualities, i.e., sweet, sour, bitter, salty, and umami. Evidence suggests that fat taste may represent the sixth taste quality [8-11]. Both humans and rodents exhibit spontaneous preference for fatty food, involving at least two known lingual lipid sensors, i.e., CD36 and GPR120 [10]. Lipid receptor activation triggers an intracellular calcium signaling cascade in taste bud cells (TBC), leading to the release of neurotransmitters that convey a lipid signal via the gustatory nerve to the brain and, thereby, may modulate eating behavior and digestive functions [9-11]. Various studies have shown that obese individuals exhibit decreased fat taste sensitivity (high detection thresholds), leading to increased intake of dietary fat in order to elicit a satiety response [12]. This low orosensory lipid perception has been principally attributed to $C D 36$ gene variations, i.e., single nucleotide polymorphisms (SNPs) that encode partially functional CD36 proteins in children, teenagers, and adult patients [11,13-15]. Indeed, CD36 protein exhibits higher affinity than GPR120 for dietary fatty acids, and the team of Nada Abumrad was the first to demonstrate an association between CD36 SNP and high orosensory detection thresholds for dietary fatty acid [16].

Besides fat taste perception, obesity is also associated with high thresholds for bitter taste [17]. Bitter tasters and non-tasters, identified with the help of 6-n-propylthiouracil (PROP), exhibit a different perception for dietary fat, and current knowledge from several studies supports the hypothesis of a critical interaction between fat and bitter taste modalities, particularly in obesity [18,19]. In most of the cases, the obese subjects have been classified as PROP non-tasters or bitter non-tasters [18-20].

The epigenetic modifications have been shown to regulate gene expression [21]. A number of such modifications have been identified, notably, RNA-mediated gene silencing, changes in chromatin folding following histone modifications, aberrant DNA hypo- or hyper-methylation, and nucleosome positioning [21,22]. Interestingly, DNA methylation, observed at $\mathrm{CpG}$ and non-CpG dinucletides, remains one of the most common epigenetic modifications [23]. CpG dinucleotides are grouped in specific regions termed "CpG islands", which primarily reside in or near to the promoters in $50 \%$ of human genes $[24,25]$. These islands become methylated when methyl groups are directly added to CpG dinucleotides, and inhibit, probably in a steric manner, the binding of trans-activating factors, leading to gene silencing $[24,26]$. C PG hypermethylation of several genes has been implicated in different pathologies, for example, colorectal cancer [27], obesity, and insulin resistance [28]. Despite the fact that CD36 and GPR120 hypermethylation was associated with their silencing $[29,30]$, there is no data on the involvement of epigenetic modifications of lipid receptors and its impact on fat taste perception. The objective of this study was to gain insight into the possible implication of an epigenetic alteration, particularly hypermethylation of CD36 and GPR120 genes, in orosensory perception of fat and bitter tastes and its relationship with preferred palatable food patterns in childhood obesity.

\section{Materials and Methods}

\subsection{Participants and Study Design}

The study population consisted of school going children $(n=102)$ from the Tlemcen district in Algeria. Children (age $=9.01 \pm 1.17$ years) were randomly selected with the help of school health-care staff that included nurses and physicians (Supplementary Material, see Figure S1). The exclusion criteria, determined by the school physician, were as follows: diabetes (fasting plasma glucose level of $\geq 126 \mathrm{mg} / \mathrm{dL}$ ), cardiovascular complications (hypertension, anatomical abnormalities in heart valves, etc.), and chronic liver pathology (determined by liver aspartate-amino transferase and alanine-amino transferase tests and X-ray examinations), etc. After medical examination, a consent form highlighting information about the purpose and the procedure of the study was read, approved, and signed by parents. Ethical guidelines for human research mentioned in the declaration of Helsinki were respected, and the experimental protocol was approved by the research council of the University of Tlemcen, and a written permission for the study was also obtained from the Regional Health Direction, 
Ministry of Health, Tlemcen (Algeria) and Regional Inspectors' of Schools, Ministry of Education, Tlemcen (Algeria) (protocol number 631, 15).

Before subjecting the participants to detection thresholds, blood samples were taken for serum and DNA analysis. Serum glucose, total cholesterol (TC), and total triglycerides (TG) concentrations were measured by the Clinical Biochemistry Department of the Tlemcen Hospital. Serum insulin concentrations were determined by ELISA as per instructions furnished with the kit (Cliniscience, Montlucon, France).

\subsection{Preferred Eating Pattern}

A questionnaire, previously employed for assessing the preferred eating pattern in Algerian children, was used before any examination [13]. In this questionnaire, a number of food items, generally served in school or at home in Algeria, were mentioned. The question was, "what do you eat preferably in the week among the listed food items", and the response was noted. In fact, we also cross-checked the children's food pattern with that of the parents' (Table S1 in the Supplementary Material).

\subsection{Orosensory Detection of Oleic Acid (OA) Thresholds}

Children, accompanied with their parents, were invited to come in the morning in a fasting condition. In fact, the children were asked to come on two different days, within a week, i.e., once for fat detection thresholds and the second time for PORP detection thresholds. After a routine medical checkup to take anthropometric parameters (height and weight), children were subjected to orosensory detection of oleic acid (OA) thresholds by a "sip and spit" technique in the ascending order of concentrations $\left(0.018,0.18,0.37,0.75,1.5,3\right.$, and $\left.12 \mathrm{mmol} \mathrm{L}^{-1}\right)$ as per 3-alternative forced-choice method (13). Briefly, three solutions were prepared, in which two contained the arabic gum as control $(0.01 \%, w / v)$, and the third one contained OA at different concentrations in arabic gum $(0.01 \%, w / v)$. The tasting sessions were conducted in an isolated room and children were offered with the first set of solutions one at a time. In the case of a negative response (non-detection of $\mathrm{OA}$ ) children were asked to taste the next set of three solutions in an ascending manner, starting from the set containing the lowest OA concentration until the presence of OA was detected. To further confirm this detection threshold, participants were given another set of three solutions with a lower concentration of fatty acid than that detected for OA. In case of no detection of this solution, OA concentration detected previously was again provided. In case of positive response, this concentration was termed as the detection threshold of OA. During the analysis and to minimize fluctuations in their responses, children were requested to rinse their mouth with spring water between each test, to wear nose clips, and to keep the solution for a few seconds in their mouths before spiting it out.

\subsection{Bitter Taste Perception Sensitivity}

The children arrived again, in a fasting condition, to participate to the second session wherein we determined bitter taste sensitivity by using PROP at three different concentrations, i.e., $0.032,0.32$, and $3.2 \mathrm{mmol} / \mathrm{L}$, and we considered them, respectively, as high, middle, and low tasters. Hence, we did not employ $\mathrm{NaCl}$ for comparison with PROP sensitivity, as we did previously [20]. Such kinds of experiments have also been performed by Manella et al. [31], without using $\mathrm{NaCl}$, to evaluate bitter taste sensitivity. The reason for excluding the $\mathrm{NaCl}$ tasting session is that this agent itself may represent a taste quality [32], and the comparison of its sensitivity with PROP, which will be, later on, used to interpret fat taste sensitivity may provide us with some misleading observations on fatty acid-bitter taste interactions. Anliker et al. [33] also excluded the use of $\mathrm{NaCl}$. Interestingly, an interaction of "salt taste" with "fat taste" has been shown wherein salt was found to promote a passive over-intake of fat [34]. 


\subsection{DNA Extraction and Conversion}

Genomic DNA was extracted from the heparinized peripheral blood of all subjects, using a commercially available kit, according to the manufacturer's instructions (Genomic Wizard, Promega, USA). Briefly, $300 \mu \mathrm{L}$ of blood was mixed with $900 \mu \mathrm{L}$ lysis buffer and the cell debris was pelleted by centrifugation $(13,000 \times g 10 \mathrm{~s})$. The pellet was suspended in $300 \mu \mathrm{L}$ Nuclei Lysis Solution $\left(37^{\circ} \mathrm{C}\right.$ for $5 \mathrm{~min}$ ), followed by the addition of $100 \mu \mathrm{L}$ of Protein Precipitation Solution. After centrifugation $(13,000 \times g 3 \mathrm{~min})$, the DNA present in the supernatant was precipitated in $300 \mu \mathrm{L}$ isopropanol, washed with $70 \%$ ethanol, rehydrated in $50 \mu \mathrm{L}$ of Rehydration Solution and stored at $-20{ }^{\circ} \mathrm{C}$ until further use. DNA integrity and concentration were determined by electrophoresis and spectrophotometry. Then, $1 \mu \mathrm{g}$ of genomic DNA was modified with sodium bisulfite using the CpGenome ${ }^{\mathrm{TM}}$ DNA Modification Kit (Chemicon, Temecula, CA, USA). After DNA conversion and purification, modified DNA was stored at $-80^{\circ} \mathrm{C}$.

\subsection{Methylation-Specific PCR (MS-PCR)}

For the methylation analysis, we selected CPG islands located at -1840 (promoter region) and -293.337 (promoter region) for GPR120 and CD36, respectively. Primers for both sequences were designed with MethPrimer [35] (Figure 1). DNA was amplified with two pairs of primers for each CpG island, one for the methylated template and the other for the unmethylated sequence, and PCR products were $178 \mathrm{bp}$ for GPR120 and $103 \mathrm{bp}$ for CD36. Primers for methylated and unmethylated sequences gave the same length of PCR products.

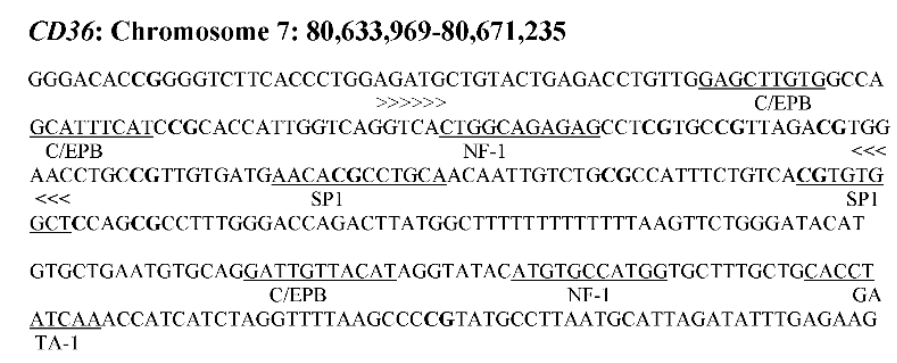

(a)

GPR120: Chromosome 10: 93,564,191-93,567,999

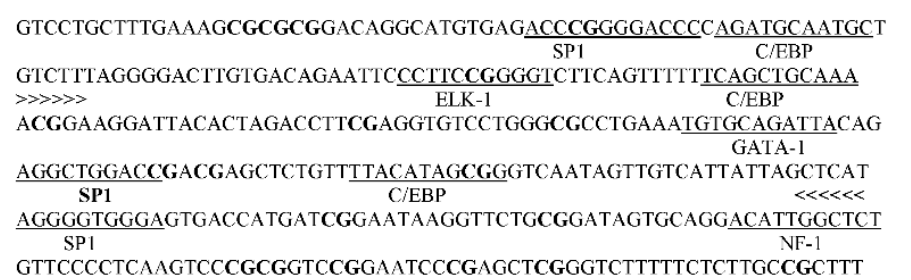

(b)

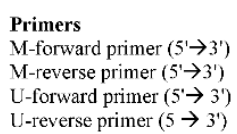

M-forward primer $\left(5^{\prime} \rightarrow 3^{\prime}\right)$
M-reverse primer $\left(5^{\prime} \rightarrow 3^{\prime}\right)$

U-forward primer $\left(5^{\prime} \rightarrow 3^{\prime}\right)$

U-reverse primer $\left(5 \rightarrow 3^{\prime}\right)$
CD36

TTAGGTTATTGGTAGAGAGTTTCGT

AAACCACACGTAACAAAAATAACG

TGGTTAGGTTATTGGTAGAGAGTTTI CCACACATAACAAAAATAACACA
GPRI20

CGGAAGGATTATATTAGATTTTCGA AAACCAATATCCTACACTATCCGC TGGAAGGATTATATTAGATTTTTGA AAACCAATATCCTACACTATCCACA

(c)

Figure 1. Selection of $\mathrm{CPG}$ island and primer design for methylation specific PCR (MS-PCR). (a) Human CD36 and (b) GPR120 CpG island sequences (promoter region). Binding sites for transcription factors are underlined. CPG sites are in bold. (c) Primer sequences used for methylation-specific PCR (MS-PCR). C/EBP: CCAAT-enhancer-binding proteins; SP1: specificity protein 1; ELK-1: Erythroblast Transformation Specific like protein 1; GATA-1: GATA-binding factor 1; NF-1: Nuclear Factor-1; >>> $<<<$ : Amplified sequence; M-forward primer: primer designed for methylated DNA; U-forward primer: forward primer designed for unmethylated DNA. 
For PCR assay, $2 \mu \mathrm{L}$ of bisulfite-modified DNA was amplified in a total volume of $25 \mu \mathrm{L}$ containing the following: $12.5 \mu \mathrm{L}$ PCR master mix (Platinum ${ }^{\mathrm{TM}}$ Hot Start PCR Master Mix, Thermo Scientific Inc., USA), $0.5 \mu \mathrm{L}$ of each of sense and antisense primers, $5 \mu \mathrm{L}$ of CG enhancer (provided with Platinum ${ }^{\mathrm{TM}}$ Master Mix), and $4.5 \mu \mathrm{L}$ nuclease-free water. PCR conditions were as follows: initial denaturation at 94 ${ }^{\circ} \mathrm{C}$ for $5 \mathrm{~min}, 40$ cycles of $95^{\circ} \mathrm{C}$ for $30 \mathrm{~s}$, annealing for $30 \mathrm{~s}\left(\mathrm{CD} 36, \mathrm{Tm}=58^{\circ} \mathrm{C}\right.$ and GPR120, $\left.\mathrm{Tm}=57^{\circ} \mathrm{C}\right)$, and $72{ }^{\circ} \mathrm{C}$ for $1 \mathrm{~min}$ followed by a final extension step at $72{ }^{\circ} \mathrm{C}$ for $8 \mathrm{~min}$. For control, we used a human methylated (positive control) and unmethylated (negative control) DNA furnished by the supplier (EpiTect PCR Control DNA set, Qiagen, USA). In positive controls, the pretreated DNA showed that the CpG were methylated and, in the same way, in negative control samples, all CpG were unmethylated. Amplification was done in the thermal cycler (iCycler C1000, Bio-Rad, Germany). Finally, $6 \mu \mathrm{L}$ of PCR product was electrophoresed on $1 \%(w / v)$ agarose gel, containing ethidium bromide. The gels were visualized by ultraviolet-light (Gel Doc imaging 2000, Bio-Rad).

\subsection{Statistical Analysis}

We used the SPSS 16.0 software for the statistical analysis (IBM, Chicago, IL, USA). The data in figures and tables are shown as means \pm SD or means \pm SEM. One-way ANOVA was used to determine the significance between measured parameters in different study groups. For correlation between BMI and taste thresholds, Spearman rank test was used. For methylation status distribution in OA and PROP orosensory detection groups between obese and lean children, Chi square and Fisher's exact tests were employed. Differences were considered significant at $p<0.05$.

\section{Results}

\subsection{Clinical and Biochemical Characteristics of the Participants}

Among the total number of children $(n=102)$ recruited in the study, 46 were boys and 56 were girls. Among them, 51 were obese $(z$-score $=2.89 \pm 0.61)$ and 51 were lean children $(z$-score $=-0.25$ \pm 1.42 ). Children were approximately of the same age group (Appendix A, Table A1). The $z$-score in the obese group was significantly higher than that of the lean group $(p<0.001)$. All the children exhibited normal blood triglyceride (TG) concentrations. However, blood cholesterol concentrations, but not HDL-cholesterol or LDL-cholesterol or triglycerides, were significantly higher in the obese group than that of the lean group $(p<0.01)$. The glycaemia was not statistically different between the two groups of participants, though obese children exhibited higher insulin concentrations than lean children (Appendix A, Table A1).

\subsection{Orosensory Perceptions of Oleic Acid and PROP}

Fatty acid oral detection sensitivity was decreased in obese children, as they exhibited a higher OA detection threshold $(6.44 \pm 0.67 \mathrm{mM})$ than lean children $(3.26 \pm 0.63 \mathrm{mM}, p=0.012)$ (Figure 2a). Interestingly, OA detection threshold was positively correlated with z-score in the whole population $(p<0.001)$ and in the obese group $(p=0.049)$, but not in lean children (Figure $2 \mathrm{~b})$. According to Daoudi et al. [14], we divided the participants on the basis of their OA detection thresholds into three groups: High-OA (from 0 to $0.018 \mathrm{mM}$ ), Middle-OA (from 0.18 to $1.5 \mathrm{mM}$ ), and Low-OA (from 3 to $12 \mathrm{mM}$ ) tasters. A significant difference was observed between z-score and OA detection thresholds $(p<0.001)$, except for High-OA and Middle-OA groups (Figure 2c). Some obese children (Non-tasters, $\mathrm{n}=18)$ were not able to detect even the highest concentration of the fatty acid $(12 \mathrm{mM})$. There were no Non-taster participants in lean children, rather there were more Middle-OA detectors in the lean group than those in the obese group of participants (Table 1). 


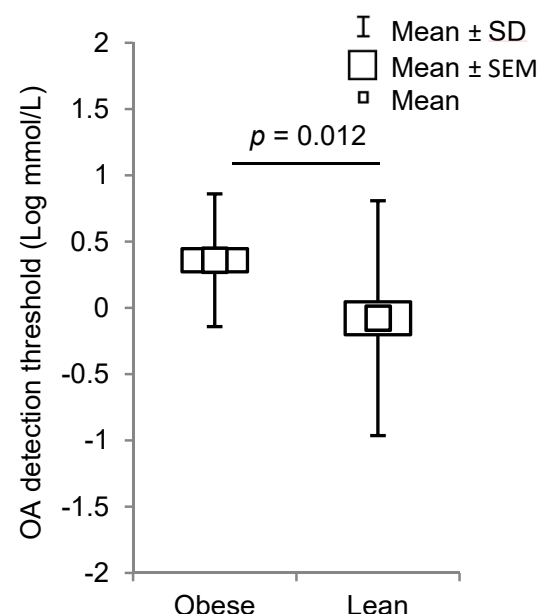

(a)

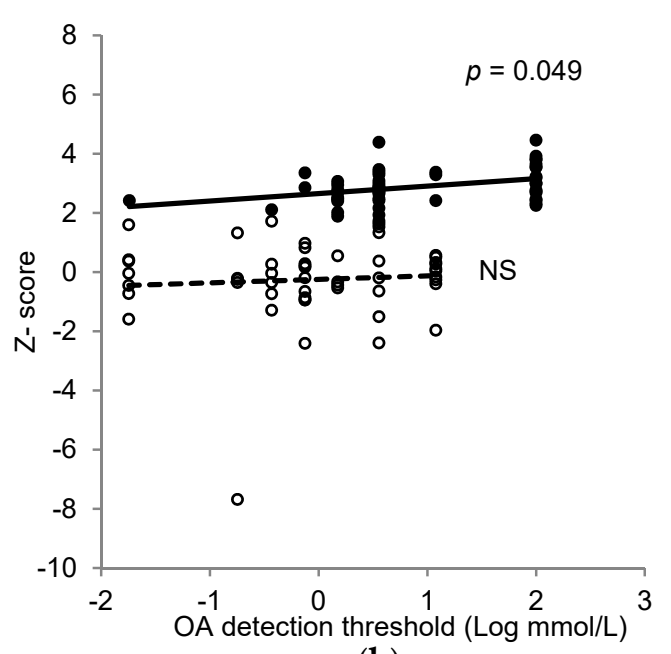

(b)

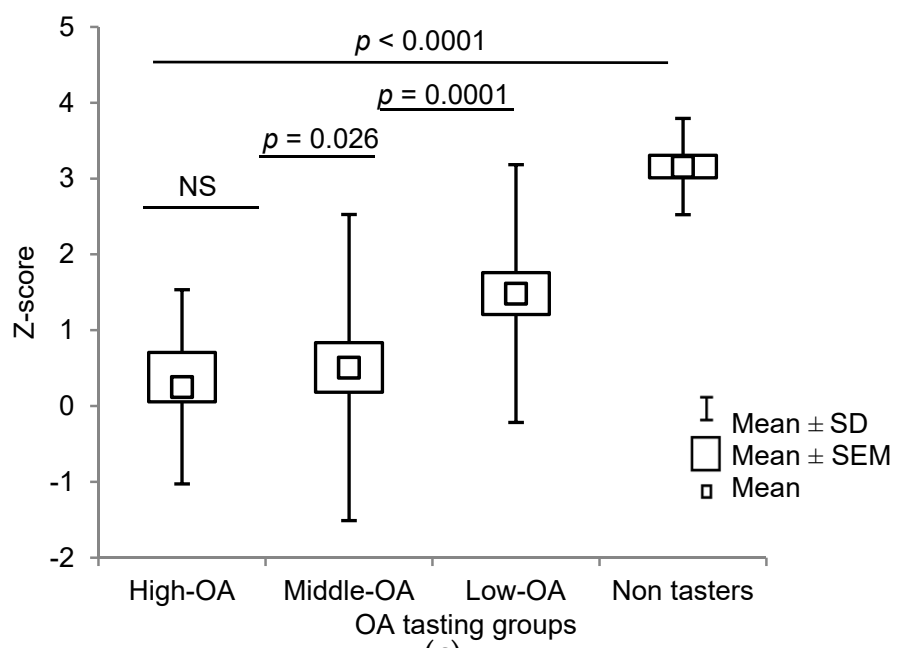

(c)

Figure 2. Relationship between obesity and oleic acid (OA) detection thresholds in lean and obese children. (a) Box plots of OA orosensory detection thresholds in lean $(n=51)$ and obese subjects $(n=33)$. (b) Spearman rank correlation between $z$-score and OA orosensory detection thresholds in all the participants $(n=84)$, (open circles: lean children; closed circles: obese children). (c): The box plots of $z$-score vs. OA detection thresholds in Low-OA, Middle-OA, High-OA, and Non-taster groups $(n=102)$. The results are means \pm SD (ANOVA and independent $t$-test); Non-tasters $(\mathrm{NT}, n=18)$; NS: not significant $(p>0.05)$.

Table 1. Number of methylated samples according to OA detection thresholds.

\begin{tabular}{ccccccc}
\hline & \multicolumn{3}{c}{$\begin{array}{c}\text { Lean Children } \\
(n=51)\end{array}$} & \multicolumn{3}{c}{$\begin{array}{c}\text { Obese Children } \\
(n=51)\end{array}$} \\
\cline { 2 - 7 } Groups & $\begin{array}{c}\text { Total } \\
(n)\end{array}$ & $\begin{array}{c}C D 36 \text { Methy. } \\
(n)\end{array}$ & $\begin{array}{c}\text { GPR120 Methy. } \\
(n)\end{array}$ & $\begin{array}{c}\text { Total } \\
(n)\end{array}$ & $\begin{array}{c}\text { CD36 Methy. } \\
(n)\end{array}$ & $\begin{array}{c}\text { GPR120 Methy. } \\
(n)\end{array}$ \\
\hline High-OA & 7 & 1 & 2 & 1 & 1 & 1 \\
\hline Middle-OA & 26 & 9 & 2 & $12^{*}$ & 12 & 8 \\
\hline Low-OA & 18 & 6 & 3 & 20 & $20^{*}$ & $11^{*}$ \\
\hline Non-tasters & 0 & 0 & 0 & 18 & 18 & 12 \\
\hline Total $(n)$ & 51 & $16(31.3 \%)$ & $7(13.7 \%)$ & 51 & $51^{*}(100 \%)$ & $32 *(62.7 \%)$ \\
\hline
\end{tabular}

Abbreviations: methy. $=$ methylation. The asterisks show the significant differences $\left({ }^{*} p<0.001\right)$ as compared to values in the respective lean participants. $\mathrm{OA}=$ oleic acid 
For bitter taste sensitivity, we noticed that obese children exhibited a higher PROP detection threshold $(0.84 \pm 1.25 \mathrm{mM})$ as compared to lean children $(0.32 \pm 0.60 \mathrm{mM})(p=0.011)$ (Figure 3a). On the basis of bitter taste sensitivity for three PROP concentrations, i.e., $0.032,0.32$, and $3.2 \mathrm{mmol} / \mathrm{L}$, we divided the participants as High-PROP (0.032 mM), Middle-PROP (0.032 mM), and Low-PROP $(3.2 \mathrm{mM})$ subjects. A significant difference was observed between $z$-score and PROP detection groups, i.e., High-PROP vs. Low-PROP, Middle-PROP vs. Low-PROP tasters (Figure 3b). There were more Middle-PROP tasters in the lean children than obese participants (Table 2). Interestingly, a positive correlation between OA and PROP detection thresholds was observed in total participants $(p=0.016)$ (Table 3, Supplementary Material, see Figure S2).

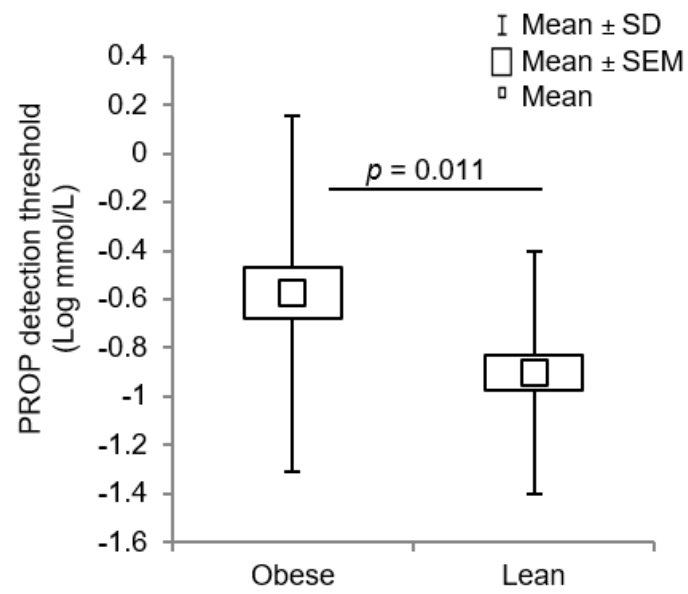

(a)

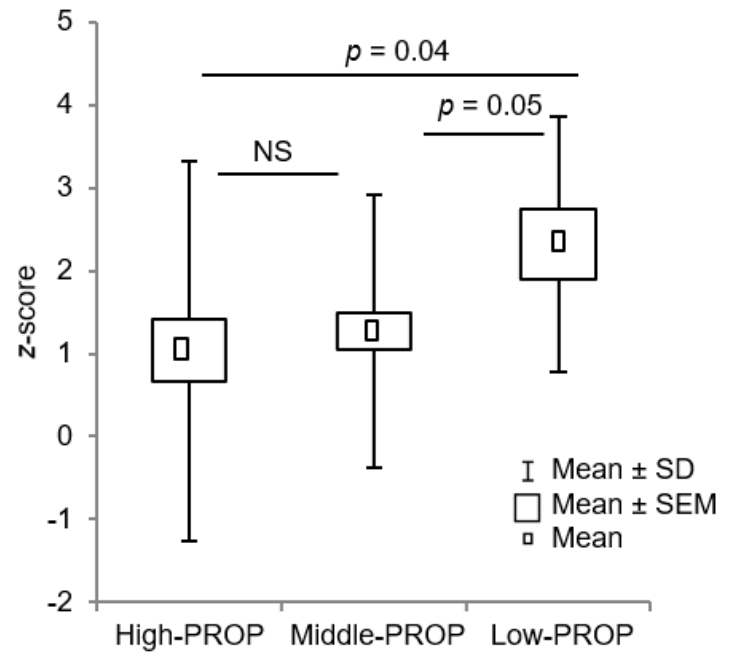

(b)

Figure 3. Relationship between obesity and 6- $n$-propylthiouracil (PROP) orosensory detection in lean and obese children. (a) Box plots of overall PROP detection thresholds in lean $(n=51)$ and obese subjects $(n=51)$. (b) The box plots of $z$-score vs. PROP detection in Low-PROP, Middle-PROP, and High-PROP groups $(n=102)$.

Table 2. Number of methylated samples according to PROP detection thresholds.

\begin{tabular}{ccccccc}
\hline \multirow{2}{*}{ Groups } & \multicolumn{3}{c}{$\begin{array}{c}\text { Lean Children } \\
(\boldsymbol{n}=\mathbf{5 1})\end{array}$} & $\begin{array}{c}\text { Obese Children } \\
(\boldsymbol{n}=\mathbf{5 1})\end{array}$ \\
\cline { 2 - 7 } & $\begin{array}{c}\text { Total } \\
(\boldsymbol{n})\end{array}$ & $\begin{array}{c}\text { CD36 Methy. } \\
(\boldsymbol{n})\end{array}$ & $\begin{array}{c}\text { GPR120 Methy. } \\
(\boldsymbol{n})\end{array}$ & $\begin{array}{c}\text { Total } \\
(\boldsymbol{n})\end{array}$ & $\begin{array}{c}\text { CD36 Methy. } \\
(\boldsymbol{n})\end{array}$ & $\begin{array}{c}\text { GPR120 Methy. } \\
(\boldsymbol{n})\end{array}$ \\
\hline High-PROP & 20 & 6 & 3 & 17 & 17 & $10^{*}$ \\
Middle-PROP & 29 & 9 & 3 & $23 * *$ & $23 *$ & $13^{* *}$ \\
Low-PROP & 2 & 1 & 1 & 11 & 11 & 9 \\
Total $(n)$ & 51 & $16(31.3 \%)$ & $7(13.7)$ & 51 & $51^{*}(100 \%)$ & $32 *(62.7 \%)$ \\
\hline
\end{tabular}

Abbreviations: methy. $=$ methylation. The asterisks show the significant differences $\left({ }^{*} p<0.001\right)$ as compared to values in the respective lean participants. PROP $=6-n$-propylthiouracil

\subsection{Methylation of CpG Islands of CD36 and GPR120 Promoters}

CD36 and GPR120 CpG islands in the promoters of CD36 and GPR120 genes were significantly more methylated in obese participants than those of lean children (Figure 4a,b). Remarkably, Tables 1 and 2 show that all the obese participants $(n=51,100 \%)$ had the $C D 36$ gene methylated, irrespective to the taster groups, though the lean children exhibited only 31\% methylation ( $n=16)$ (Tables 1 and 2). As regards GPR120, there were more obese children that exhibited methylation as compared to lean participants (Tables 1 and 2; lean children, $n=7,13 \%$ vs. obese subjects, $n=32,62 \%, p<0.01$ ). We also noticed that CD36 and GPR120 methylation was positively correlated to $z$-score and plasma cholesterol (Appendix A, Table A2). 
Table 3. Number of children according to their OA and PROP orosensory detection thresholds in the whole population.

\begin{tabular}{ccccc}
\hline \multirow{2}{*}{$\begin{array}{c}\text { OA Thresholds } \\
\text { (mmol/L) }\end{array}$} & \multicolumn{4}{c}{$\begin{array}{c}\text { PROP Detection Threshold } \\
\text { (mmol/L) }\end{array}$} \\
\cline { 2 - 5 } & $\mathbf{0 . 0 3 2}$ & $\mathbf{0 . 3 2}$ & $\mathbf{3 . 2}$ & Total \\
\hline 0.018 & 4 & 4 & 0 & 8 \\
0.18 & 1 & 4 & 0 & 5 \\
0.37 & 4 & 3 & 0 & 7 \\
0.75 & 6 & 7 & 0 & 13 \\
1.5 & 5 & 4 & 4 & 13 \\
3.6 & 11 & 12 & 2 & 25 \\
12 & 1 & 10 & 2 & 13 \\
Non taster & 5 & 8 & 5 & 18 \\
Total $(n)$ & 37 & 52 & 13 & 102 \\
\hline
\end{tabular}
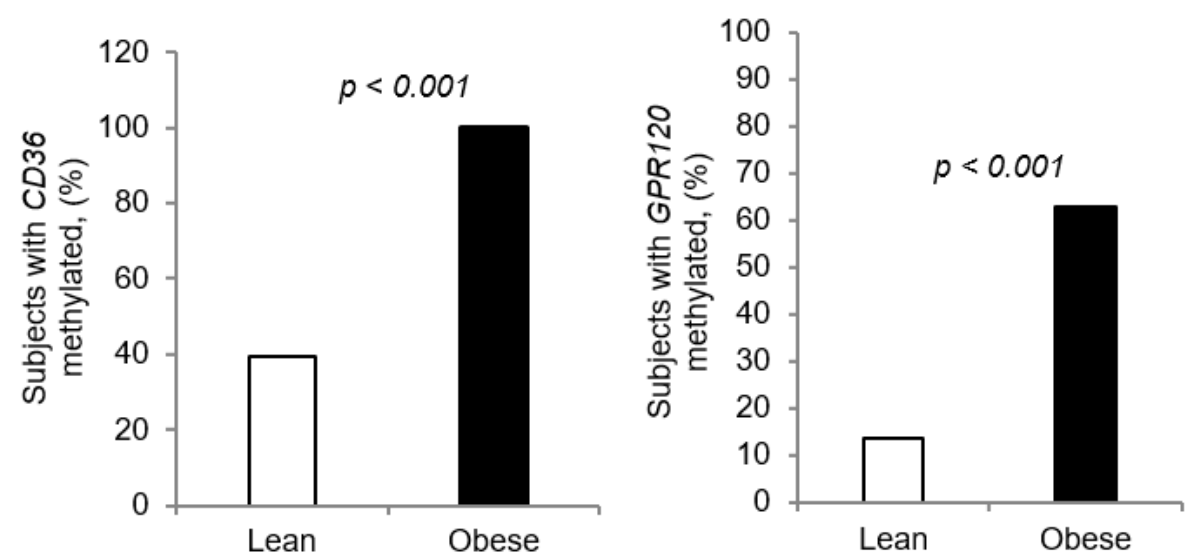

Figure 4. CD36 and GPR120 CpG islands methylation expressed as percentage: (a) Comparison of DNA methylation of CD36 CpG island between lean $(n=51)$ and obese subjects $(n=51)$. (b) Comparison of GPR120 CpG island methylation between lean $(n=51)$ and obese subjects $(n=51)$ (chi square test).

It was also observed that, except for the High-OA group, the difference in CD36 and GPR120 methylation between obese and lean children was significant in Middle-OA, Low-OA, and Non-taster groups, based on their OA oral sensitivity (Figure $5 a, b$ ).

In PROP detection groups, we noticed a significant difference in CD36 methylation between obese and lean children in High-PROP, Middle-PROP, and Low-PROP groups (Figure 6a); however, no significant difference in GPR120 methylation was detected in the Low-PROP group between obese and lean children (Figure $6 \mathrm{~b}$ ). We noted a positive correlation between lipid sensor (CD36 and GPR120) methylation and OA perception thresholds (Appendix A, Table A2). However, lipid sensors methylation was not significantly correlated to PROP detection thresholds (Appendix A, Table A2). 


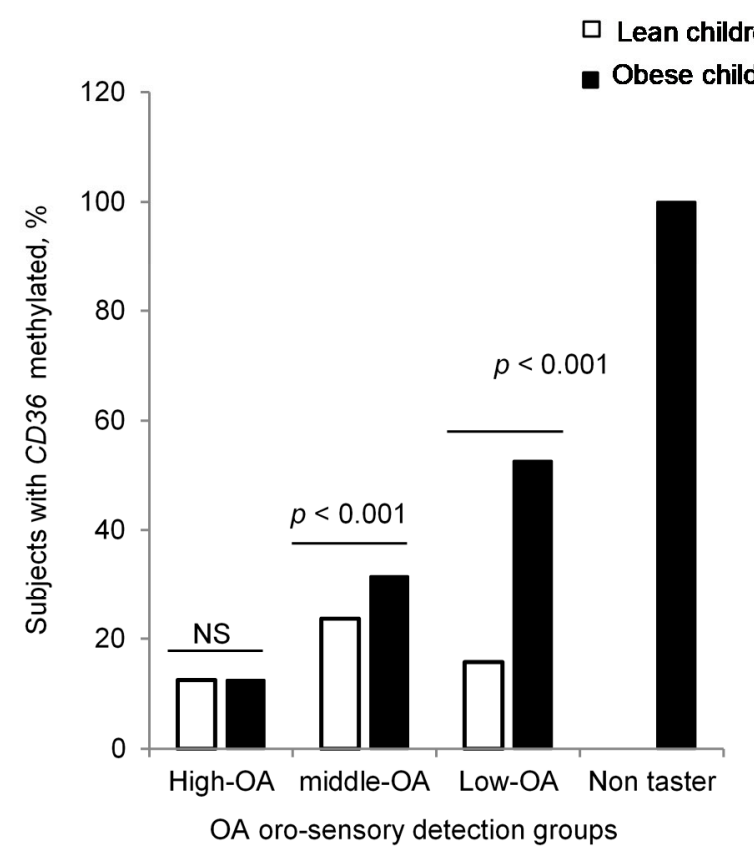

(a)

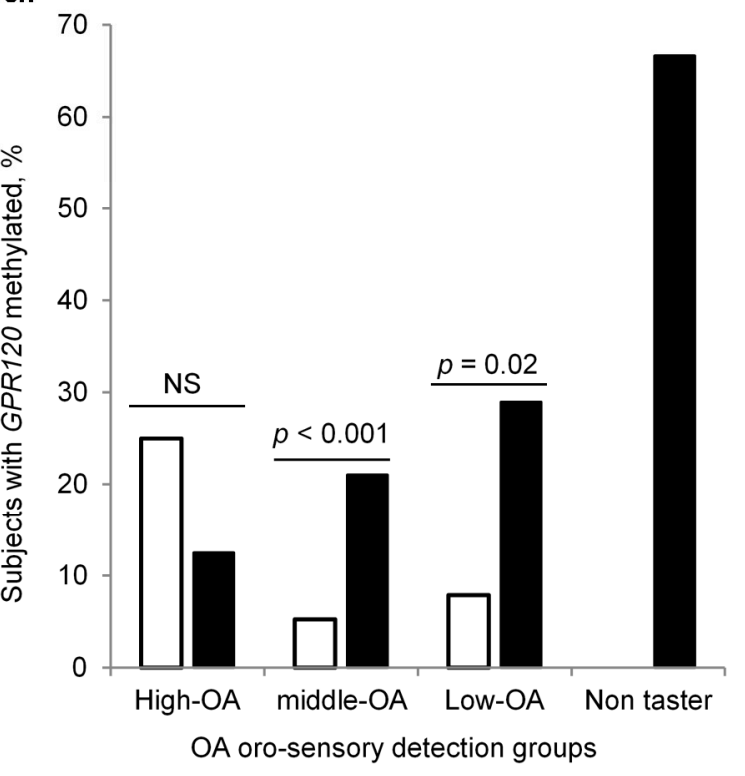

(b)

Figure 5. CD36 and GPR120 CpG islands methylation in different groups. Comparison of DNA methylation of (a) CD36 CpG island and (b) GPR120 CpG island between lean and obese subjects (chi square test, fisher exact test).

$\square$ Lean children

- Obese children

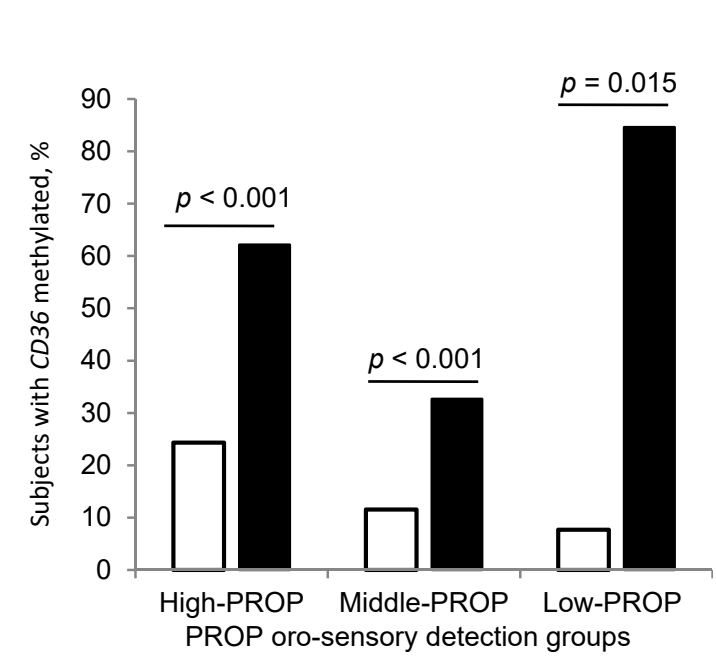

(a)

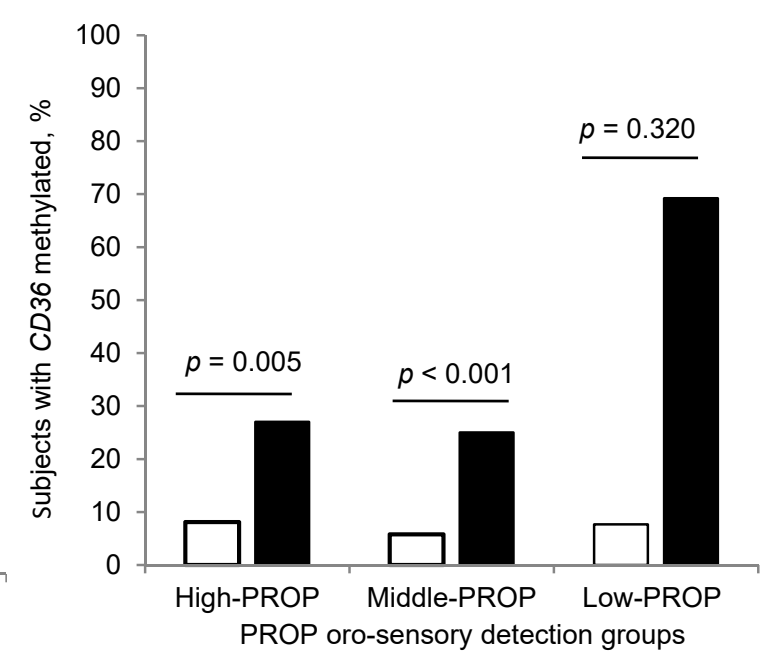

(b)

Figure 6. CD36 and GPR120 CpG islands methylation in PROP taster groups. Comparison of DNA methylation of (a) CD36 CpG island and (b) GPR120 CpG island between lean and obese subjects (chi square test, fisher exact test).

\subsection{Preferred Eating Pattern in Obese Children}

The eating behavior questionnaire revealed that obese children significantly preferred fat-rich palatable food items like chips, cheese, and chocolate, whereas lean children preferred home-made food items (Supplementary Material, see Table S2). Furthermore, the children that liked fat-rich food had a 
high degree of CD36 and GPR120 methylation (Table 4). There was also a positive correlation between methylation of CD36 and GPR120 genes and intake of calories from highly palatable food items.

Table 4. Relationship between preferred food pattern and CD36/GPR120 methylation.

\begin{tabular}{ccccc}
\hline Food Contents & $\begin{array}{c}\text { Unmethylated } \\
\text { CD36 }\end{array}$ & $\begin{array}{c}\text { Methylated } \\
\text { CD36 }\end{array}$ & $\begin{array}{c}\text { Unmethylated } \\
\text { GPR120 }\end{array}$ & $\begin{array}{c}\text { Methylated } \\
\text { GPR120 }\end{array}$ \\
\cline { 2 - 5 } & Total $(n=35)$ & Total $(n=67)$ & Total $(n=63)$ & Total $(n=38)$ \\
\hline $\begin{array}{c}\text { Meat, chips, } \\
\text { cheese, breads } \\
\text { and chocolate }\end{array}$ & 7 & $49 *$ & 25 & $31^{*}$ \\
\hline $\begin{array}{c}\text { Home prepared } \\
\text { food (parents } \\
\text { restrictions) and candy }\end{array}$ & 28 & $18^{*}$ & 38 & $8^{*}$ \\
\hline
\end{tabular}

Fisher exact test, ${ }^{*} p<0.0001$. The asterisks show the significant differences as compared to values in the respective lean participants.

\section{Discussion}

During the last decade, the relationship between obesity, including childhood obesity, and oro-gustatory detection of fat has been a matter of great attention. Two lipid sensors, CD36 and GPR120, have been shown to play an essential role in the orosensory detection of fat. In addition, an interaction between bitter and lipid taste modalities has been reported [18,19]. Since CpG methylation also results in decreased gene expression, we focused on the relationship between CpG methylation of two lipid sensors, CD36 and GPR120, and the orosensory perception of a fatty acid, i.e., oleic acid (OA), and a bitter taste agonist, i.e., 6-n-propylthiouracil (PROP), in lean and obese Algerian children.

We observed that obese children exhibited a decreased detection capacity for OA, with a positive correlation between OA detection thresholds and BMI $z$-scores, though there is some debate of using BMI $z$-score as a predictor of adiposity changes in obese children. In our study, BMI $z$-score was used as a screening tool for obesity and not for monitoring change in adiposity patterns, on which Vanderwall et al. have elegantly reported [36]. Furthermore, we pooled and classified all the participants (lean and obese) on the basis of OA detection thresholds, into three categories, i.e., High-OA, Middle-OA, and Low-OA tasters [14]. Interestingly, the Low-OA group exhibited significantly higher BMI $z$-score than the Middle- and High-OA groups. The lean participants belonged to High-OA group. It is noteworthy that the Non-taster group, which consisted of only obese children ( $n=18,35 \%$ ), exhibited the highest $z$-scores compared to that of the Low-OA group. We can allude that non-tasting capacity or a severe hyposensitivity to fatty acid detection could contribute to enhanced dietary fat intake and, consequently, to increased BMI. These observations corroborate our previous study on 6-7 years old Algerian obese children [13] and adult participants [14,15,37,38].

As far as bitter sensitivity is concerned, we noticed that obese children exhibited low sensitivity to the bitterness of PROP, compared to lean children, in accordance with our previous studies on adult obese [20]. Furthermore, we observed a strong correlation between OA and PROP detection sensitivity in these children [20]. Hence, an alteration in fatty acid detection may have an impact on bitter taste mechanism and vice versa. Indeed, there seems to be a "cross-talk" between fat and bitter taste modalities. The hypothesis of a "bitter-like fat taste" is also getting support, most probably via downstream signaling mechanisms, coupled to fat sensors and bitter receptors in taste bud cells $[17,18,39]$. Pittman et al. observed that the addition of a fatty acid (linoleic or oleic acid) to solutions containing a bitter substance decreased bitter perception in rats [40]. Nonetheless, the present study strengthens the notion that there might be a "bitter-like fat taste" component in fat taste signaling. That is also the reason that some of the subjects refer to fat taste as scratchy or burning [18]. A bitter receptor could be involved in textural perception of dietary fat [33]. It is also possible that there exists an indirect cooperation between fat and bitter taste receptors, via trophic factors, 
which through their autocrine or paracrine action may modulate taste sensitivity in the intra-papillary microenvironment [41,42]. During the postprandial phase of fat intake, there also might exist an identical mechanism via the entero-endocrine axis, triggered by either bitter ligands or fatty acids to induce the secretion of gut peptides like CCK and GLP-1 [43-45].

Several researchers have demonstrated that the loss (or decreased) of fat taste sensitivity in obese subjects may arise from single nucleotide polymorphisms (SNPs), responsible for reduced or curtailed expression of lipid sensors, i.e., CD36 and GPR120 [13,14,18,46,47]. Besides genetic polymorphisms, epigenetic changes such as DNA methylation of lipid receptors may constitute one of the potential mechanisms underlying the development of childhood obesity. It is well established that DNA methylation is associated with condensed nuclease-resistant heterochromatin and silencing of gene expression [48]. The team, led by Nada Abumrad, has elegantly shown that the CD36 SNPs also associate with CD36 DNA methylation at $\mathrm{CpG}$ sites, and this was associated with reduced CD36 mRNA expression and modulation of postprandial lipid uptake [49]. Our results clearly showed high methylation of both CD36 and GPR120 genes in obese children, where, surprisingly, all (100\%) of them were CD36 methylated. As far as OA detection threshold is concerned, we noticed that Middle-OA, Low-OA, and Non-taster obese groups exhibited methylation of CD36 and GPR120 genes. This was not the case in the High-OA group, where methylation of CD36 and GR120 genes was not significantly different between lean and obese participants. In addition, we observed a significant positive correlation between $z$-scores and OA detection threshold in children with methylated CD36 and GPR120. Indeed, both CD36 and GPR120 are involved in the transduction of the fat signal, though they exhibit different affinities for fatty acids [11]. We have recently shown that both CD36 and GPR120 are differently involved in fat taste perception. The CD36 seems to control immediate early detection of fat, whereas GPR120 seems to control postprandial regulation of fat ingestion [10]. A future challenge is to clarify the potential mechanism that relates CD36 and/or GPR120 methylation to decreased fat and/or bitter oral sensitivity. Unluckily, we did not have the opportunity to investigate mRNA expression as programmed in our study design. Another limitation of our study is that we isolated DNA from blood cells, and the epigenetic profiles including DNA methylation are tissue specific [50]. It was practically difficult for us to isolate taste bud DNA as the ethical committee did not approve collecting of the taste bud papillae in children.

However, based on the hypothesis that CpG methylation of both CD36 and GPR120 may induce reduced mRNA expression, we observed a significant correlation between lipid receptor methylation (CD36 and GPR120) and bitter/PROP detection thresholds in obese children. This suggests that lipid receptor signaling might interact with bitter taste sensitivity (as mentioned above). Another important part of our study is the association between obesity and preferred food items, rich in calories, in accordance with our previous study on Algerian young obese children [13]. Most interestingly, the preference for the calorie-rich food pattern was associated with methylation of CD36 and GPR120. Future studies are required to shed light on how dietary fat triggers such epigenetic modifications, i.e., CD36 or GPR120 methylation, though dietary caloric restriction ( $30 \%$ of less caloric daily intake) for 8 weeks resulted in weight loss and decreased CD36 DNA methylation at CpG sites [51]. Feeding a high fat diet to pregnant rats results in a high DNA methylation pattern of several genes including CD36 and PPAR- $\gamma$ in male offspring [52]. Besides, dietary monounsaturated and $n-6$ polyunsaturated fatty acids have been shown to increase DNA methylation of pro-inflammatory cytokines like TNF- $\alpha$ in obese subjects [53,54]. We can assume that an epigenetic change in CD36, observed in the present study, may also modulate proinflammatory status in obese children as CD36 also controls the activation of macrophages that release in high quantities the pro-inflammatory cytokines like IL-6, IL-1, and TNF- $\alpha$.

Some authors have demonstrated that bitter taste perception varies as a function of the density of fungiform papillae; the higher the density, the higher the bitter (and most probably fat) taste perception. However, in the present study, we did not determine the fungiform taste bud densities, as such relationships have been debated by Hayes et al. who found no link between decreased bitter taste perception and fungiform density [55]. 
An overall perusal of our results strengthens the relationship between methylation of lipid sensors, high lipid thresholds, and a high preference pattern for fatty food items in obesity. A surprising aspect is that all the obese children had CD36 gene methylated, though all the obese did not show the same thresholds for OA or PROP. Whether CD36 gene methylation also controls other factors like PPARinvolved in obesity remains unanswered, but if yes, what does it control and how is it regulated? Is this a particular feature of the Tlemcen district where consanguine marriages are prevalent? [56] This aspect requires confirmation in another population in the world or in another part of the same country. Ours is the first report on GPR120 methylation, fat/bitter perception, and obesity, and our results remain to be confirmed in another population on adult participants. In our report, the CpG islands are localized in the putative binding site for the transcription factors EBP and SP1, involved in various functions including regulation of apoptosis, cell cycle, and adipogenesis. What is the transcriptional and physiological relevance of these particular transcription factors in childhood obesity? Nothing is known, except that there might be an interplay between PPAR- and EBP, and SP1 might be involved in reprogramming of gene transcription [57].

\section{Conclusions}

Our study confirms the positive correlation between fat and bitter taste alteration during obesity in children. Hence, we can propose that CD36 and GPR120 gene methylation and/or expression could be used, in association with other known factors, as markers of obesity in children, though further research is mandatory to clarify exactly the nature of such an association.

Supplementary Materials: The following is available online at http://www.mdpi.com/2077-0383/9/6/1956/s1, Figure S1: Participant flow chart, Figure S2: Correlation between OA detection threshold and PROP detection threshold in the whole population, Table S1: Food preferences questionnaire, Table S2: Relationship between preferred food pattern and obesity.

Author Contributions: Conceptualization, N.A.K.; methodology, N.A.K. and M.B.; validation, N.A.K.; formal analysis, M.B. and A.H.; investigation, M.B.; resources, A.H. and A.S.K.; writing-original draft preparation, M.B.; writing-review and editing, N.A.K.; visualization, L.A.-K.; supervision, N.A.K. and L.A.-K.; project administration, N.A.K. and A.H.; funding acquisition, N.A.K. and A.H. All authors have read and agreed to the published version of the manuscript.

Funding: This study was supported by a grant from the French National Research Agency (ANR-11-LABX-0021LipSTIC). Researcher travel was funded by the Pharmacy Department, Faculty of Medicine, University of Tlemcen, Algeria.

Acknowledgments: The authors thank the research participants for their contributions to the research. The authors also thank Henni Chader and Mohammed Amin Benhazil for their valuable research assistance.

Conflicts of Interest: The authors declare no conflict of interest.

\section{Appendix A}

Table A1. Characteristics and biochemical parameters of control and obese participants.

\begin{tabular}{|c|c|c|c|}
\hline Parameters & $\begin{array}{l}\text { Lean Children }{ }^{1} \\
\quad(n=51)\end{array}$ & $\begin{array}{c}\text { Obese Children }{ }^{1} \\
(n=51)\end{array}$ & $p$ Values $^{2}$ \\
\hline Age (years) & $9.31 \pm 0.86$ & $8.87 \pm 1.39$ & 0.05 \\
\hline$z$-score & $-0.25 \pm 1.42$ & $2.89 \pm 0.61$ & $<0.001$ \\
\hline Glycaemia (mg/dL) & $0.77 \pm 0.1$ & $0.77 \pm 0.10$ & 0.83 \\
\hline Cholesterol (g/L) & $0.56 \pm 0.18$ & $0.83 \pm 0.34$ & $<0.001$ \\
\hline Insulin $(\mathrm{pmol} / \mathrm{L})$ & $3.77 \pm 0.01$ & $3.80 \pm 0.04$ & $<0.001$ \\
\hline Triglycerides (g/L) & $1.39 \pm 0.22$ & $1.38 \pm 0.26$ & 0.85 \\
\hline LDL-C (mmol/L) & $2.53 \pm 0.61$ & $2.60 \pm 0.50$ & 0.80 \\
\hline HDL-C (mmol/L) & $1.10 \pm 0.32$ & $1.24 \pm 0.42$ & 0.84 \\
\hline
\end{tabular}

${ }^{1}$ Values are means $\pm \mathrm{SD}^{2}$ Student's $t$-test. 
Table A2. Correlations between different parameters.

\begin{tabular}{|c|c|c|c|c|c|c|c|c|}
\hline $\begin{array}{c}\text { Genes } \\
\text { Promoter } \\
\text { Regions }\end{array}$ & $\begin{array}{c}\text { Serum } \\
\text { Glucose }(\mathrm{g} / \mathrm{L})\end{array}$ & $\begin{array}{c}\text { Serum } \\
\text { Triglycerides } \\
(\mathrm{g} / \mathrm{L})\end{array}$ & $\begin{array}{c}\text { Serum } \\
\text { Cholesterol } \\
(\mathrm{g} / \mathrm{L})\end{array}$ & $\begin{array}{l}\text { Serum } \\
\text { Insulin }\end{array}$ & $z$-Score & $\begin{array}{l}\text { OA } \\
\text { Perception } \\
\text { Threshold }\end{array}$ & $\begin{array}{c}\text { PROP } \\
\text { Perception } \\
\text { Threshold } \\
\end{array}$ & $\begin{array}{l}\text { Calories } \\
\text { Intake/Day }\end{array}$ \\
\hline $\begin{array}{l}\text { Methylated } \\
\text { CD36 }\end{array}$ & $\begin{array}{c}0.145 \\
p=0.146\end{array}$ & $\begin{array}{c}-0.039 \\
p=0.516\end{array}$ & $\begin{array}{c}0.252 \\
p=0.007\end{array}$ & $\begin{array}{c}0.260 \\
p=0.015\end{array}$ & $\begin{array}{c}0.610 \\
p<0.001\end{array}$ & $\begin{array}{c}0.407 \\
p<0.001\end{array}$ & $\begin{array}{c}0.132 \\
p=0.185\end{array}$ & $\begin{array}{c}0.628 \\
p<0.01\end{array}$ \\
\hline $\begin{array}{l}\text { Methylated } \\
\text { GPR120 }\end{array}$ & $\begin{array}{c}-0.067 \\
p=0.402\end{array}$ & $\begin{array}{c}-0.135 \\
p=0.980\end{array}$ & $\begin{array}{c}0.285 \\
p=0.004\end{array}$ & $\begin{array}{c}0.211 \\
p=0.50\end{array}$ & $\begin{array}{c}0.442 \\
p<0.001\end{array}$ & $\begin{array}{c}0.265 \\
p=0.007\end{array}$ & $\begin{array}{c}0.163 \\
p=0.103\end{array}$ & $\begin{array}{c}0.520 \\
p<0.01\end{array}$ \\
\hline
\end{tabular}

\section{References}

1. Afshin, A. Health Effects of Overweight and Obesity in 195 Countries over 25 Years. New Engl. J. Med. 2017, 377, 13-27. [CrossRef] [PubMed]

2. Lew, E.A.; Garfinkel, L. Variations in mortality by weight among 750,000 men and women. J. Chronic Dis. 1979, 32, 563-576. [CrossRef]

3. Rivera-Dommarco, J.; Barquera, S.; Campirano, F.; Campos-Nonato, I.; Safdie, M.; Tovar, V. Epidemiological and nutritional transition in Mexico: Rapid increase of non-communicable chronic diseases and obesity. Public Heal. Nutr. 2002, 5, 113-122. [CrossRef]

4. Popkin, B.M.; Adair, L.S.; Ng, S.W. Global nutrition transition and the pandemic of obesity in developing countries. Nutr. Rev. 2012, 70, 3-21. [CrossRef]

5. Flegal, K.M.; Carroll, M.; Ogden, C.L.; Curtin, L.R. Prevalence and Trends in Obesity Among US Adults, 1999-2008. JAMA 2010, 303, 235. [CrossRef]

6. Reilly, J.J.; Kelly, J. Long-term impact of overweight and obesity in childhood and adolescence on morbidity and premature mortality in adulthood: Systematic review. Int. J. Obes. 2010, 35, 891-898. [CrossRef]

7. Daniels, S.R.; Arnett, D.K.; Eckel, R.H.; Gidding, S.S.; Hayman, L.L.; Kumanyika, S.; Robinson, T.N.; Scott, B.J.; Jeor, S.S.; Williams, C.L. Overweight in Children and Adolescents. Circulation 2005, 111, 1999-2012. [CrossRef]

8. Chaudhari, N.; Roper, S. The cell biology of taste. J. Cell Boil. 2010, 190, 285-296. [CrossRef]

9. Gilbertson, T.; Khan, N.A. Cell signaling mechanisms of oro-gustatory detection of dietary fat: Advances and challenges. Prog. Lipid Res. 2014, 53, 82-92. [CrossRef] [PubMed]

10. Ozdener, M.H.; Subramaniam, S.; Sundaresan, S.; Šerý, O.; Hashimoto, T.; Asakawa, Y.; Besnard, P.; Abumrad, N.A.; Khan, N.A. CD36- and GPR120-mediated $\mathrm{Ca}^{2+}$ signaling in human taste bud cells mediates differential responses to fatty acids and is altered in obese mice. Gastroenterology 2014, 146, 995-1005. [CrossRef] [PubMed]

11. Besnard, P.; Passilly-Degrace, P.; Khan, N.A. Taste of Fat: A Sixth Taste Modality? Physiol. Rev. 2016, 96, 151-176. [CrossRef] [PubMed]

12. Khan, A.S.; Keast, R.; Khan, N.A. Preference for dietary fat: From detection to disease. Prog. Lipid Res. 2020, 78, 101032. [CrossRef] [PubMed]

13. Sayed, A.; Šerý, O.; Plesník, J.; Daoudi, H.; Rouabah, A.; Rouabah, L.; Khan, N.A.; Hadjer, D. CD36 AA genotype is associated with decreased lipid taste perception in young obese, but not lean, children. Int. J. Obes. 2015, 39, 920-924. [CrossRef] [PubMed]

14. Daoudi, H.; Plesník, J.; Sayed, A.; Šerý, O.; Rouabah, A.; Rouabah, L.; Khan, N.A. Oral Fat Sensing and CD36 Gene Polymorphism in Algerian Lean and Obese Teenagers. Nutrients 2015, 7, 9096-9104. [CrossRef] [PubMed]

15. Mrizak, I.; Šerý, O.; Plesník, J.; Arfa, A.; Fekih, M.; Bouslema, A.; Zaouali, M.; Tabka, Z.; Khan, N.A. The A allele of cluster of differentiation 36 (CD36) SNP 1761667 associates with decreased lipid taste perception in obese Tunisian women. Br. J. Nutr. 2015, 113, 1330-1337. [CrossRef]

16. Pepino, M.Y.; Love-Gregory, L.; Klein, S.; Abumrad, N.A. The fatty acid translocase gene CD36 and lingual lipase influence oral sensitivity to fat in obese subjects. J. Lipid Res. 2011, 53, 561-566. [CrossRef]

17. Khan, A.S.; Murtaza, B.; Hichami, A.; Khan, N.A. A crosstalk between fat and bitter taste modalities. Biochimie 2019, 159, 3-8. [CrossRef]

18. Khan, A.S.; Hichami, A.; Khan, N.A. Taste perception and its effects on oral nutritional supplements in younger life phases. Curr. Opin. Clin. Nutr. Metab. Care 2018, 21, 411-415. [CrossRef] 
19. Melis, M.; Sollai, G.; Muroni, P.; Crnjar, R.; Barbarossa, I.T. Associations between Orosensory Perception of Oleic Acid, the Common Single Nucleotide Polymorphisms (rs1761667 and rs1527483) in the CD36 Gene, and 6-n-Propylthiouracil (PROP) Tasting. Nutrients 2015, 7, 2068-2084. [CrossRef]

20. Karmous, I.; Plesník, J.; Khan, A.S.; Šerý, O.; Abid, A.; Mankai, A.; Aouidet, A.; Khan, N.A. Orosensory detection of bitter in fat-taster healthy and obese participants: Genetic polymorphism of CD36 and TAS2R38. Clin. Nutr. 2018, 37, 313-320. [CrossRef]

21. Bird, A. Perceptions of epigenetics. Nature 2007, 447, 396-398. [CrossRef]

22. Feinberg, A.P.; Tycko, B. The history of cancer epigenetics. Nat. Rev. Cancer 2004, 4, 143-153. [CrossRef] [PubMed]

23. Ehrlich, M. DNA methylation in cancer: Too much, but also too little. Oncogene 2002, 21, 5400-5413. [CrossRef]

24. Jin, J.; Lian, T.; Gu, C.; Yu, K.; Gao, Y.Q.; Su, X.-D. The effects of cytosine methylation on general transcription factors. Sci. Rep. 2016, 6, 29119. [CrossRef] [PubMed]

25. Caiafa, P.; Zampieri, M. DNA methylation and chromatin structure: The puzzling CpG islands. J. Cell. Biochem. 2005, 94, 257-265. [CrossRef] [PubMed]

26. Sawan, C.; Vaissière, T.; Murr, R.; Herceg, Z. Epigenetic drivers and genetic passengers on the road to cancer. Mutat. Res. Mol. Mech. Mutagen. 2008, 642,1-13. [CrossRef] [PubMed]

27. Xu, X.-L.; Yu, J.; Zhang, H.-Y.; Sun, M.-H.; Gu, J.; Du, X.; Shi, D.-R.; Wang, P.; Yang, Z.-H.; Zhu, J.-D. Methylation profile of the promoter $\mathrm{CpG}$ islands of 31 genes that may contribute to colorectal carcinogenesis. World J. Gastroenterol. 2004, 10, 3441-3454. [CrossRef]

28. García-Cardona, M.C.; Huang, F.; García-Vivas, J.M.; López-Camarillo, C.; Navarro, B.E.D.R.; Olivos, E.N.; Hong-Chong, E.; Bolaños-Jiménez, F.; A Marchat, L. DNA methylation of leptin and adiponectin promoters in children is reduced by the combined presence of obesity and insulin resistance. Int. J. Obes. 2014, 38, 1457-1465. [CrossRef]

29. Keller, M.; Hopp, L.; Liu, X.; Wohland, T.; Rohde, K.; Cancello, R.; Klös, M.; Bacos, K.; Kern, M.; Eichelmann, F.; et al. Genome-wide DNA promoter methylation and transcriptome analysis in human adipose tissue unravels novel candidate genes for obesity. Mol. Metab. 2016, 6, 86-100. [CrossRef]

30. Díaz, M.; García, C.; Sebastiani, G.; López-Bermejo, A.; Ibáñez, L.; de Zegher, F. Placental and Cord Blood Methylation of Genes Involved in Energy Homeostasis: Association with Fetal Growth and Neonatal Body Composition. Diabetes 2016, 66, 779-784. [CrossRef]

31. Mennella, J.A.; Pepino, M.Y.; Reed, D.R. Genetic and environmental determinants of bitter perception and sweet preferences. Pediatrics 2005, 115, e216-e222. [CrossRef] [PubMed]

32. Liman, E.R. Salty Taste: From Transduction to Transmitter Release, Hold the Calcium. Neuron 2020, 106, 709-711. [CrossRef] [PubMed]

33. Anliker, J.A.; Bartoshuk, L.; Ferris, A.M.; Hooks, L.D. Children's food preferences and genetic sensitivity to the bitter taste of 6-n-propylthiouracil (PROP). Am. J. Clin. Nutr. 1991, 5, 316-320. [CrossRef] [PubMed]

34. Bolhuis, D.; Costanzo, A.; Newman, L.P.; Keast, R. Salt Promotes Passive Overconsumption of Dietary Fat in Humans. J. Nutr. 2015, 146, 838-845. [CrossRef]

35. Li, L.-C.; Dahiya, R. MethPrimer: Designing primers for methylation PCRs. Bioinformatics 2002, 18, $1427-1431$. [CrossRef]

36. Vanderwall, C.; Eickhoff, J.C.; Clark, R.R.; Carrel, A.L. BMI z-score in obese children is a poor predictor of adiposity changes over time. BMC Pediatr. 2018, 18, 187. [CrossRef]

37. Haryono, R.Y.; Sprajcer, M.A.; Keast, R. Measuring oral fatty acid thresholds, fat perception, fatty food liking, and papillae density in humans. J. Vis. Exp. 2014, e51236. [CrossRef]

38. Chevrot, M.; Passilly-Degrace, P.; Ancel, D.; Bernard, A.; Enderli, G.; Gomes, M.; Robin, I.; Issanchou, S.; Vergès, B.; Nicklaus, S.; et al. Obesity interferes with the orosensory detection of long-chain fatty acids in humans. Am. J. Clin. Nutr. 2014, 99, 975-983. [CrossRef] [PubMed]

39. Tepper, B.J.; Koelliker, Y.; Zhao, L.; Ullrich, N.V.; Lanzara, C.; D’Adamo, P.; Ferrara, A.; Ulivi, S.; Esposito, L.; Gasparini, P.; et al. Variation in the Bitter-taste Receptor GeneTAS2R38, and Adiposity in a Genetically Isolated Population in Southern Italy. Obesity 2008, 16, 2289-2295. [CrossRef] [PubMed]

40. Pittman, D.; Labban, C.E.; Anderson, A.A.; O'Connor, H.E. Linoleic and Oleic Acids Alter the Licking Responses to Sweet, Salt, Sour, and Bitter Tastants in Rats. Chem. Senses 2006, 31, 835-843. [CrossRef] [PubMed]

41. Mattes, R.D. Effects of linoleic acid on sweet, sour, salty, and bitter taste thresholds and intensity ratings of adults. Am. J. Physiol. Liver Physiol. 2007, 292, G1243-G1248. [CrossRef] [PubMed] 
42. Lee, A.; Owyang, C. Sugars, Sweet Taste Receptors, and Brain Responses. Nutrients 2017, 9, 653. [CrossRef] [PubMed]

43. Dotson, C.D.; Zhang, L.; Xu, H.; Shin, Y.-K.; Vigues, S.; Ott, S.H.; Elson, A.; Choi, H.J.; Shaw, H.; Egan, J.M.; et al. Bitter Taste Receptors Influence Glucose Homeostasis. PLoS ONE 2008, 3, e3974. [CrossRef]

44. Hirasawa, A.; Tsumaya, K.; Awaji, T.; Katsuma, S.; Adachi, T.; Yamada, M.; Sugimoto, Y.; Miyazaki, S.; Tsujimoto, G. Free fatty acids regulate gut incretin glucagon-like peptide-1 secretion through GPR120. Nat. Med. 2004, 11, 90-94. [CrossRef]

45. Chen, M.C.; Wu, S.V.; Reeve, J.R.; Rozengurt, E. Bitter stimuli induce Ca2+ signaling and CCK release in enteroendocrine STC-1 cells: Role of L-type voltage-sensitive Ca2+ channels. Am. J. Physiol. Physiol. 2006, 291, C726-C739. [CrossRef] [PubMed]

46. Ichimura, A.; Hirasawa, A.; Poulain-Godefroy, O.; Bonnefond, A.; Hara, T.; Yengo, L.; Kimura, I.; Leloire, A.; Liu, N.; Iida, K.; et al. Dysfunction of lipid sensor GPR120 leads to obesity in both mouse and human. Nature 2012, 483, 350-354. [CrossRef]

47. Waguri, T.; Goda, T.; Kasezawa, N.; Yamakawa-Kobayashi, K. The combined effects of genetic variations in the GPR120 gene and dietary fat intake on obesity risk. Biomed. Res. 2013, 34, 69-74. [CrossRef] [PubMed]

48. Newell-Price, J.; Clark, A.J.; King, P. DNA Methylation and Silencing of Gene Expression. Trends Endocrinol. Metab. 2000, 11, 142-148. [CrossRef]

49. Love-Gregory, L.; Kraja, A.T.; Allum, F.; Aslibekyan, S.; Hedman, Å.K.; Duan, Y.; Borecki, I.B.; Arnett, N.K.; McCarthy, M.I.; Deloukas, P.; et al. Higher chylomicron remnants and LDL particle numbers associate withCD36SNPs and DNA methylation sites that reduceCD36. J. Lipid Res. 2016, 57, 2176-2184. [CrossRef]

50. Zhou, J.; Sears, R.; Xing, X.; Zhang, B.; Li, D.; Rockweiler, N.; Jang, H.S.; Choudhary, M.N.; Lee, H.J.; Lowdon, R.F.; et al. Tissue-specific DNA methylation is conserved across human, mouse, and rat, and driven by primary sequence conservation. BMC Genom. 2017, 18, 724. [CrossRef]

51. Amaral, C.L.; Milagro, F.I.; Curi, R.; Martínez, J.A. DNA Methylation Pattern in Overweight Women under an Energy-Restricted Diet Supplemented with Fish Oil. BioMed Res. Int. 2014, 2014, 1-10. [CrossRef] [PubMed]

52. Yu, H.-L.; Dong, S.; Gao, L.-F.; Li, L.; Xi, Y.-D.; Ma, W.-W.; Yuan, L.-H.; Xiao, R. Global DNA methylation was changed by a maternal high-lipid, high-energy diet during gestation and lactation in male adult mice liver. Br. J. Nutr. 2015, 113, 1032-1039. [CrossRef] [PubMed]

53. Milagro, F.I.; Gómez-Abellán, P.; Campión, J.; Martínez, J.A.; Ordovás, J.M.; Garaulet, M. CLOCK, PER2 and BMAL1 DNA Methylation: Association with Obesity and Metabolic Syndrome Characteristics and Monounsaturated Fat Intake. Chrono Int. 2012, 29, 1180-1194. [CrossRef] [PubMed]

54. Hermsdorff, H.H.M.; Mansego, M.L.; Campion, J.; Milagro, F.I.; Zulet, M.A.; Martínez, J.A. TNF-alpha promoter methylation in peripheral white blood cells: Relationship with circulating TNF $\alpha$, truncal fat and n-6 PUFA intake in young women. Cytokine 2013, 64, 265-271. [CrossRef] [PubMed]

55. Hayes, J.E.; Bartoshuk, L.M.; Kidd, J.R.; Duffy, V.B. Supertasting and PROP Bitterness Depends on More Than the TAS2R38 Gene. Chem. Senses 2008, 33, 255-265. [CrossRef] [PubMed]

56. Aribi, M.; Sari, B.-E.; Saari, B. Effect of Endogamy and Consanguinity on the Development of LabialVenous Malformations in rea of Tlemcen (West Algeria). Open Genom. J. 2008, 1, 1-8. [CrossRef]

57. Madsen, M.S.; Siersbæk, R.D.; Boergesen, M.; Nielsen, R.; Mandrup, S. Peroxisome Proliferator-Activated Receptor $\gamma$ and C/EBP $\alpha$ Synergistically Activate Key Metabolic Adipocyte Genes by Assisted Loading. Mol. Cell. Boil. 2013, 34, 939-954. [CrossRef]

(C) 2020 by the authors. Licensee MDPI, Basel, Switzerland. This article is an open access article distributed under the terms and conditions of the Creative Commons Attribution (CC BY) license (http://creativecommons.org/licenses/by/4.0/). 